\title{
Palaeolimnology in eastern and southern Australian estuaries
}

\author{
John Tibby $\cdot$ Kathryn H. Taffs
}

Received: 1 November 2011/Accepted: 2 November 2011/Published online: 22 November 2011

(C) Springer Science+Business Media B.V. 2011

\section{Introduction}

Palaeolimnology has been widely used in freshwater environments, providing information for policy development and legislation (Bennion and Battarbee 2007; Battarbee and Bennion 2011). However, application of palaeolimnology in coastal environments remains challenging (Cooper 2010). The application of palaeolimnological techniques in coastal ecosystems was pioneered by Cooper and Brush (1991), Juggins (1992), Andren (1999) and Kerfoot et al. (1999). These methods have required some adaptations (Cooper 2000; Cooper et al. 2004), but have been effectively utilised in many Northern Hemisphere estuaries. For example, studies of the Baltic Sea (Kauppila et al. 2005; Clarke et al. 2006; Weckstrom 2006; Tuovinen et al. 2010), Chesapeake Bay (Cooper and Brush 1993; Cooper 1995, 1999, Cooper et al. 2004), Florida Bay (Wachnicka et al. 2010, 2011) and the Pearl River estuary in southern China (Zong et al. 2010) have produced results that provide information useful to managers. Yet, in the Southern Hemisphere,

J. Tibby $(\bowtie)$

Geography, Environment and Population, University of Adelaide, Adelaide, SA 5005, Australia e-mail: john.tibby@adelaide.edu.au

\section{K. H. Taffs}

Southern Cross Geoscience, Southern Cross University, PO Box 157, Lismore, NSW 2480, Australia

e-mail: kathryn.taffs@scu.edu.au and in particular Australia, application of palaeolimnological methods in coastal environments remains in its infancy (Saunders and Taffs 2009).

In general, palaeolimnology in Australia is underutilised, yet offers many possibilities for a continent that has experienced dramatic landscape change over a short period of time that is rarely fully documented. In particular, information on Australian estuaries is urgently required to assist management actions where there are substantial population pressures and multiple conflicting uses of coastal environments (Saunders and Taffs 2009). However, applying palaeolimnological techniques to Australian estuaries is particularly problematic because of the paucity of information on Australian estuary functioning. While it is well understood that estuaries are highly dynamic ecosystems (Cooper 1999), the variability of estuarine function across climatic zones is still being actively researched (Eyre and Balls 1999; Bowen and Valiela 2008). Australian estuaries function quite differently to their Northern Hemisphere counterparts (Davis and Koop 2006), hence palaeolimnological methods largely developed in the Northern Hemisphere need to be applied with some caution in Australia.

The greatest cause of these differences is that rainfall frequency is much lower, with episodic rain events controlling chemical and biological functioning (Davis and Koop 2006). Hence, average water residence time is often higher than in less variable ecosystems with equivalent freshwater inputs, resulting in a dominance of internal nutrient cycling. 
Suspended sediment concentrations are generally much higher in Australian than many Northern Hemisphere estuaries (Davis and Koop 2006), resulting in high concentration of water column nutrients and decreased light penetration (Eyre 2000). This affects the biology of the system with planktonic micro-organisms dominating over benthic forms (Harris 1999).

The recent application of palaeolimnology in Australian coastal environments has highlighted its potential value, particularly for assisting management of estuaries and coastal lakes (Fluin et al. 2007; Haynes et al. 2007; Saunders et al. 2007, 2008; Taffs et al. 2008). While this approach is not without limitations, these can be minimised (Saunders and Taffs 2009). For example, site selection within estuaries is critical given their dynamism, particularly in relation to establishing an accurate chronology (Crusius et al. 2004). Locating estuarine sites of constant sediment accumulation is possible (Cooper et al. 2004), but extraction of multiple cores from such depositional areas and the use of multiple indicators within each core, can help reduce the effects of filtering (Swetnam et al. 1999), poor fossil preservation (Ryves et al. 2001) and distinguishing between autochthonous and allochthonous inputs (Vos and de Wolf 1993). Furthermore, advances in chronological and statistical methodologies now allow temporally precise quantitative reconstructions.

This special edition of the Journal of Paleolimnology is a collection of innovative Australian palaeolimnological studies. Most use standard techniques applied in the Northern Hemisphere and, to some extent, test their viability and propose necessary adaptations. This is an important step for palaeolimnology in Australia and identifies some challenges for its future development.

\section{Methodological approaches and their relevance to Australian estuarine palaeolimnology}

Statistical developments in the recent past have enabled robust quantitative reconstructions of water quality with reasonable certainty. However, this is generally in regions with a large number of sites and where modern analogues exist. In some cases, a range of sites within a region is not available and either an internal dataset (Mackay et al. 2003) or qualitative methods are the only options available. The former is often the case in Australia where surface water resources are scarce. For example, in the Yarra River catchment (Victoria) the diatom-TP model cited in Gell et al. (2005) was developed from repeated sampling of four lakes. Secondly, some sites are unique, for example Myall Lake on the central New South Wales coast (Drew et al. 2008) and, hence, developing diatom data sets to infer water quality in such sites is likely to fail. Compounding this problem is the modification of unique sites, which renders the development of "internal" training sets with good analogues impossible (Haynes et al. 2011). Quantitative methods have been trialled in Australian coastal environments (MacGregor et al. 2005; Saunders et al. 2008; Taffs et al. 2008), with qualitative approaches also applied (Fluin et al. 2007; Haynes et al. 2007). In the qualitative studies, inferences were drawn from Australian and global diatom research.

It is axiomatic that a detailed knowledge of the relationship between biological proxies and environmental variables must be established before inferences about past environments can be generated. In the Northern Hemisphere, many collaborative datasets have been established that can be applied over large regions (e.g. European Diatom Database, Battarbee et al. 2011; North America, Spaulding et al. 2010). In Australia, very few diatom data sets exist, with fewer still from estuaries (Saunders et al. 2008). This is due to the large area of the continent, the paucity of surface water resources and the early developmental stage of palaeolimnological science. Despite the cosmopolitan nature of many diatoms (Bennett et al. 2010), caution is needed in utilising ecological tolerances derived from distant locations, even for qualitative reconstructions since there is regional differentiation in the ecology of cosmopolitan diatoms (Telford et al. 2006).

\section{Modern diatom-environment relationships in Australian estuaries}

A key requirement for palaeolimnology in Australia is an increased understanding of proxy-environment relationships. In this volume, the understanding of coastal diatom ecology is extended by Grinham et al. (2011) who focus on the relationship between benthic diatoms in a sub-tropical estuarine embayment. Grinham et al. (2011) took on this challenge in the 
highly dynamic Moreton Bay which has posed problems for palaeolimnology (Logan et al. 2010). Sediment type was the main driver of diatom composition and short term fluctuations of water chemistry had minimal impacts (Grinham et al. 2011). Hence, estuarine palaeolimnology needs to account for the nature of sediments and, particularly, shifts in sediment that, through their influence on diatom composition, could be interpreted as changes in water quality.

The relationship between diatoms and environmental variables was further explored by Saunders (2011) and Haynes et al. (2011) through the development of transfer functions. These contributions expand knowledge from the earlier work of Hodgson and Tyler (1996) and Saunders et al. (2007). Saunders (2011) has constructed a salinity transfer function over a very large region (36 sites from 32 Tasmanian estuaries and 45 sites within 13 Victorian estuaries), covering over $1,500 \mathrm{~km}$ of coastline. Salinity was the strongest environmental variable and a diatom-salinity model was developed.

Haynes et al. (2011) studied the relationship between diatoms and water chemistry in The Coorong, a unique elongate coastal lake. An internal transfer function was attempted for both diatoms and foraminifera. A diatom-salinity model was successfully constructed. However, the foraminifera assemblage lacked sufficient abundance and diversity to construct a robust model. Haynes et al. (2011) identify some of the problems of palaeolimnology in a unique coastal ecosystem. In this case, although a robust model was developed, there has been substantial modification to this system, meaning that there are poor analogues in the fossil record. The large errors in both Saunders and Haynes et al. (2011) (RMSEP $=0.09 \log$ ppt and $16 \mathrm{~g} \mathrm{l}^{-1}$ salinity, respectively), highlight the need for more research such as Grinham et al.'s (2011) to better document influences other than salinity on diatom composition.

\section{Dating Australian estuarine sediments}

Dating sediment sequences remains a challenge in Australian coastal ecosystems. Many aspects of this challenge are not restricted to coastal environments or indeed Australia. Of particular concern is the chronological gap between sediment that can be dated using ${ }^{210} \mathrm{~Pb}$ (generally $<150$ years and often considerably less; Sloss et al. 2011; Hollins et al. 2011) and that can be reliably dated using ${ }^{14} \mathrm{C}$, without the need to "wiggle match" using a large number of ages (i.e. in sediment younger than approximately $400{ }^{14} \mathrm{C}$ yr BP; Hua 2009). This problem is particularly pertinent since the first evidence of European impact in palaeolimnological records is often derived from some aspect of the sediments themselves (Leyden et al. 2011; Hollins et al. 2011). Such an approach can introduce a degree of circularity to the conclusions drawn in these circumstances. Other factors such as the mobility of ${ }^{137} \mathrm{Cs}$ in saline environments (Hancock and Hunter 1999; Leyden et al. 2011) or the lower concentrations of atmospheric ${ }^{137} \mathrm{Cs}$ in the Southern Hemisphere (Leslie and Hancock 2008) are problems that affect estuaries and those located in Australia more particularly.

In studies that evaluate the history of estuaries, the selection of material to be dated is a challenge. Estuarine sediments are made up of components derived from the marine environment, freshwater catchments and estuaries themselves (Lamb et al. 2006). This mixture of sources means that even a simple exercise such as the selection of an appropriate calibration curve or reservoir corrections for ${ }^{14} \mathrm{C}$ dates is a substantial challenge. Several papers in this special issue investigate the application of dating techniques in Australian coastal environments.

To document the effect of catchment clearance on coastal lake sedimentation, Sloss et al. (2011) contrast recent sedimentation rates in two New South Wales coastal lakes that have similar dimensions and climate, but differing amounts of catchment forest clearance. In addition, they compare these rates with the presettlement rates previously determined. Sloss et al. (2011) apply both the commonly used ${ }^{210} \mathrm{~Pb}$ and ${ }^{137} \mathrm{Cs}$ techniques, along with aspartic acid racemisation dating of molluscs to obtain ages of recent sediments. Sloss et al. (2011) suggest that increased sedimentation rates in Lake Illawarra are due to the more urbanised nature of its catchment. In addition, they demonstrate that the sedimentation rate increases recorded in St Georges Basin occur in the limited part of that catchment that has been cleared. Although Sloss et al. (2011) highlight that their work is preliminary, the faster rates of racemisation in Batillaria australis mean that this mollusc may provide precise young ages (i.e. $<500$ years) and thereby provide an opportunity to bridge the gap between ${ }^{14} \mathrm{C}$ and ${ }^{210} \mathrm{~Pb}$ dates. 
Hollins et al. (2011) similarly assess evidence for post-settlement increased sedimentation from two small coastal lakes in urban Wollongong on the New South Wales south coast. Whilst it is clear that sediments have accumulated rapidly, particularly since the 1970s, direct comparison with pre-settlement sedimentation was complicated by the fact that, at some sites, there is clear evidence of sediment scouring and reworking (demonstrated by inverted ${ }^{14} \mathrm{C}$ ages). Also highlighted was an overall increase in sediment heavy metal concentrations in the two lagoons and, particularly, an enrichment with Zinc (Hollins et al. 2011).

Logan and Taffs (2011) and Logan et al. (2011) used magnetic inclination and loss on ignition profiles to determine core integrity prior to applying expensive analyses. Following these analyses, the most intact sediment record was selected for further analysis and dating. Even after this iterative process, ${ }^{210} \mathrm{~Pb}$ dating of sediments from a large protected marine embayment was not successful (Logan and Taffs 2011). Retrieved sediments contained large proportions of marine sand (Logan and Taffs 2011) to which ${ }^{210} \mathrm{~Pb}$ does not readily adhere (Álvarez-Iglesias et al. 2007; Vaalgamaa and Korhola 2007). Alpha and gamma spectrometry were unable to detect sufficient ${ }^{210} \mathrm{~Pb}$ activity to produce a chronology, even on sediments from the $<63 \mu \mathrm{m}$ component. However, AMS ${ }^{14} \mathrm{C}$ methods produced dates in chronological sequence, providing a viable chronology for older sediments in this estuary.

In a sub-tropical river-dominated estuary Logan et al. (2011) were able to successfully ${ }^{210} \mathrm{~Pb}$ date the upper portions of sediments with alpha spectrometry, enabling correlation to historical landuse changes. Unfortunately, at this site, the historical period sediments lay almost directly above those of mid-Holocene age. This prevented an assessment of changes in sediment accumulation rates, and also a full contrast of the pre- and post-European settlement conditions.

\section{Inferring estuary history from biological indicators}

Logan and Taffs (2011) and Logan et al. (2011) use diatom data, augmented by stable $\mathrm{C}$ and $\mathrm{N}$ isotopes to evaluate the history of the two most northerly situated estuaries in this special issue. These records are different both in length and nature. The diatom-based history of the Richmond River estuary is short (dating to c. $1940 \mathrm{CE}$ ). This study highlighted the importance of climate in driving the nutrient status of the estuary, with peaks in diatom inferred total phosphorus associated with higher rainfall, with no distinct trend of increasing nutrients detected (Logan et al. 2011). Given the substantial interannual and interdecadal variability in rainfall in this region, palaeolimnological data are important to ensure that water quality trends associated with climate are not attributed to human agency (Logan et al. 2011). Logan et al. (2011) also show that while the ${ }^{13} \delta \mathrm{C}$ composition of the sedimentary organic matter was largely unchanging, the ${ }^{15} \delta \mathrm{N}$ record was more variable. As is frequently the case (Lamb et al. 2006), interpretation of this record was not straightforward. However, there was a general consistency between the diatom and ${ }^{15} \delta \mathrm{N}$ records.

Logan and Taffs (2011) argue that identifying true reference sites is important for developing an increased understanding of estuary function and to improve the management of estuaries. Their study assesses the history of Burrum River estuary, a site identified as "largely unmodified" (Geoscience Australia 2011) and therefore a candidate for such evaluations. They show that the assumed "largely unmodified" status of this site is in accordance with its palaeolimnological history. This finding is important since unimpacted sites are rare on the eastern Australian coast and because the assumed character of estuaries is not always correct (Dick et al. 2011; Leyden et al. 2011; Logan and Taffs 2011)

Leyden et al. (2011) assessed evidence for purported plant loss in Bombah Broadwater in the Myall Lakes system using plant and animal macrofossils. Leyden et al. (2011) found no evidence of the loss of plants and, in addition, found strong evidence for postsettlement freshening of this site. They attribute the freshening of this site to land clearance induced increases in run off.

Dick et al. (2011) use the macrofossil record from the south lagoon of The Coorong, South Australia, to evaluate the fate of a keystone species, the macrophyte Ruppia tuberosa. As is often the case with such studies (Tibby et al. 2007), the results contrasted with expectations. Rather than being the dominant plant in the pre-European sediments, $R$. tuberosa was only found in the post-settlement sediments, with another macrophyte, Ruppia megacarpa instead the dominant plant in this system for at least 3,000 years.

These studies (Leyden et al. 2011; Dick et al. 2011) highlight the value of hypothesis-driven 
palaeolimnology since they assess specific issues in relation to the understanding of coastal lakes. Interestingly, in both cases the history of these systems was considerably broader than would have been predicted from even detailed contemporary studies.

\section{Prospects for the future of coastal palaeolimnology in Australia}

Improved dating of coastal lake sediments

Studies in this issue have highlighted a number of challenges to developing accurate sediment chronologies in estuaries. In addressing this challenge, Logan and Taffs (2011) and Sloss et al. (2011) highlight that better chronologies are likely to emerge in the future from the application of magnetic inclination and amino acid racemisation approaches.

Beyond the scope of this issue, Hancock et al. (2011) have highlighted the potential of Pu to refine chronologies of recent sediments in Australia, including those from estuaries. Pu can be used in a similar manner to ${ }^{137} \mathrm{Cs}$ to identify sediments deposited after the expansion of atmospheric nuclear weapons testing in the mid 1950s. As such it provides an important independent test of ${ }^{210} \mathrm{~Pb}$ dating. However, the lower detection limits, longer half life and a lower mobility render Pu more useful than ${ }^{137} \mathrm{Cs}$ for this purpose. In addition, changes in the isotopic ratio of $\mathrm{Pu}$ in the mid to late 1960s provide an additional marker horizon (Hancock et al. 2011).

Estuarine palaeolimnology and Australian Holocene climate

In terms of the unfulfilled potential of coastal palaeolimnology, there has been little explicit evaluation of the influence of climate on these systems. However, it is clear that estuaries record changes in catchment run off through freshening (Leyden et al. 2011), the transport of riverine diatoms from upstream (Logan and Taffs 2011) or through increased nutrient concentrations resulting from inwash (Logan et al. 2011). This information, in combination with increasingly sophisticated understanding of estuarine evolution and sea level history (Sloss et al. 2011) could facilitate a much greater understanding of changes in Holocene moisture regime in eastern Australia.
The potential for reconstructing coastal lake functioning

Studies in this volume (Logan and Taffs 2011; Logan et al. 2011) and earlier research (MacGregor et al. 2005; Fluin et al. 2007; Tibby et al. 2007; Taffs et al. 2008) have demonstrated the value of diatoms in inferring past water quality in Australian coastal lakes. These reconstructions have provided valuable insights into aspects of past "structural" features of coastal lakes (in particularly water quality). However, through diatoms it may be possible to analyse the fossil record for more insights into the changing function of coastal lakes over time.

Diatoms play a pivotal role in the biogeochemistry of coastal lakes and estuaries in Australia (Haese et al. 2007). In particular, diatoms are fundamental to denitrification as they remove $\mathrm{N}$ from the water column through uptake followed by frustule sinking and hence rendering it "available" to sediment bacteria to breakdown. Given the important link between diatoms and estuarine processes, it may be possible to go beyond the structural diatom-based reconstructions outlined herein to develop more insights into the past function of estuaries. This might be possible by, for example, identifying changes in the net rate of diatom flux to the sediments or, more speculatively, by identifying assemblages associated with different denitrification efficiencies.

In terms of obtaining records of key ecosystem functions, lessons from the freshwater realm may be particularly instructive. Sayer et al. (2010) have shown, through careful study of the contemporary functioning of shallow lakes, the representation of sediment remains and palaeolimnology it is possible to reconstruct key processes associated with the loss of plants in eastern English lakes. Similar approaches could elucidate the history of seagrasses and other angiosperms in estuaries.

Coastal lake palaeolimnology and environmental management

Following earlier research (Saunders and Taffs 2009), the papers in this special issue have highlighted the need for palaeolimnological studies to be used in "management". However, there is no explicit discussion of the way in which this should occur. In this context, while research in this special issue clearly 
demonstrates the impact of European land and water management on estuaries, a challenge for coastal lake palaeolimnologists undertaking applied studies is to develop both specific recommendations and an effective means for communicating such recommendations. Without such strategies, palaeolimnological research is unlikely to be widely used by managers. In contrast to this somewhat negative assessment, it may take a number of years for the utility of palaeolimnological studies to be recognised. As an example, recently results of diatom studies of coastal Lake Alexandrina and The Coorong (Fluin et al. 2007) have been used in the development of a long term planning strategy for the ecosystems (DEH 2010). Indeed, a map identifying the extent of freshwater and marine incursions based on diatom data features prominently (DEH 2010, p. 16). This recent use of lower Murray River diatom studies which commenced over a decade ago (Barnett 1994) highlights the possible longevity of such research. However, such experiences appear exceptions, rather than the norm.

In terms of developing further understanding that can be used as a basis for management, there is considerable potential to the use palaeolimnology of coastal lakes to assess the accuracy of classifications of coastal lakes that are largely based on their current status (sensu Logan and Taffs 2011).

\section{Conclusions}

The sites for palaeolimnological investigation included in this special issue ranged from a latitude of $25^{\circ} \mathrm{S}$ (Burrum River in Queensland) to $43^{\circ} \mathrm{S}$ (Tasmania), and included both tropical and temperate climates. These sites were scattered along the vast southern and eastern coastlines, clearly indicating that only a very limited proportion of the Australian coastline has been investigated, with no sites from Western Australia or the tropical north of Australia examined in this issue.

Research in this issue has contributed to a much more specific understanding of the nature and extent of alterations to coastal ecosystems. Sloss et al. (2011) and Hollins et al. (2011) define the extent of sedimentation in NSW estuaries, with Hollins et al. (2011) also identifying heavy metal inputs. While such impacts can, to some extent, be predicted through modelling (Wilkinson et al. 2004), Sloss et al. (2011) and Hollins et al. (2011) provide much more specific understanding. By contrast, a number of studies in this volume have provided understanding of estuarine alteration that could not have otherwise been predicted. Studies of both The Coorong and Bombah Broadwater (Myall Lakes) have provided evidence of aquatic plant community composition and change that contrast markedly with current understanding (Dick et al. 2011 and Leyden et al. 2011, respectively).

This issue lays the foundation for future palaeolimnological studies in Australian estuaries. This is achieved through both the development of data sets that are useful beyond the specific study and through the successful demonstration of particular approaches. In the former category are diatom-salinity preferences and models (Haynes et al. 2011; Saunders 2011) and amino acid racemisation rates (Sloss et al. 2011). In the latter category are the demonstrated utility of stable isotope (Logan and Taffs 2011 and Logan et al. 2011) and macrofossil techniques (Dick et al. 2011; Leyden et al. 2011).

This compilation of papers provides the opportunity to assess the application of palaeolimnology in Australian estuarine environments. It furthers our understanding of environmental change over time, the evolution of the Australian coastal environment and the manner in which humans have interacted with that environment. This special issue should reinvigorate estuarine palaeolimnology in scientific and management fields.

\section{References}

Álvarez-Iglesias P, Quintana B, Belén R, Pérez-Arlucea M (2007) Sedimentation rates and trace metal input history in intertidal sediments from San Simón Bay (Ría de Vigo, NW Spain) derived from ${ }^{210} \mathrm{~Pb}$ and ${ }^{137} \mathrm{Cs}$ chronology. J Environ Radioact 98:229-250

Andren E (1999) Changes in the composition of the diatom flora during the last century indicate increased eutrophication of the Oder Estuary, south-western Baltic Sea. Estuar Coast Shelf Sci 48:665-676

Barnett EJ (1994) A Holocene paleo-environmental history of Lake Alexandrina, South Australia. J Paleolimnol 12:259268

Battarbee RW, Bennion H (2011) Palaeolimnology and its developing role in assessing the history and extent of human impact on lake ecosystems. J Paleolimnol 45: 399-404

Battarbee RW, Juggins S, Gasse F, Anderson NJ, Bennion H, Cameron NG (2000) European Diatom Database (EDDI). 
An information system for palaeoenvironmental reconstruction. In: Proceedings of European climate science conference, pp 1-10

Battarbee RW, Morley D, Bennion H, Simpson GL, Hughes M, Bauere V (2011) A palaeolimnological meta-database for assessing the ecological status of lakes. J Paleolimnol 45:405-414

Bennett JR, Cumming BF, Ginn BK, Smol JP (2010) Broadscale environmental response and niche conservatism in lacustrine diatom communities. Glob Ecol Biogeogr 19:724-732

Bennion H, Battarbee R (2007) The European Union Water Framework Directive: opportunities for palaeolimnology. J Paleolimnol 38:285-295

Bowen JL, Valiela I (2008) Using $\delta 15$ to assess coupling between watersheds and estuaries in temperate and tropical regions. J Coast Res 24:804-813

Clarke AL, Weckstrom K, Conley DJ, Anderson NJ, Adser F, Andren E, de Jonge VN, Ellegaard M, Juggins S, Kauppila P, Korhola A, Reuss N, Telford RJ, Vaalgamaa S (2006) Long-term trends in eutrophication and nutrients in the coastal zone. Limnol Oceanogr 51:385-397

Cooper SR (1995) Chesapeake Bay watershed historical landuse: impact on water quality and diatom communities. Ecol Appl 5:703-723

Cooper SR (1999) Estuarine paleoenvironmental reconstruction using diatoms. In: Stoermer E, Smol JP (eds) The diatoms: applications for the environmental and earth sciences. Cambridge University Press, Cambridge

Cooper SR (2000) The history of water quality in North Carolina estuarine waters as documented in the stratigraphic record. North Carolina State University. Available at http://www. lib.ncsu.edu/resolver/1840.4/1930

Cooper SR (2010) Estuarine paleoenvironmental reconstruction using diatoms. In: Smol JP, Stoermer E (eds) The diatoms: applications for the environmental and earth sciences, 2nd edn. Cambridge University Press, Cambridge

Cooper SR, Brush GS (1991) Long-term history of Chesapeake Bay anoxia. Science 254:992-996

Cooper SR, Brush GS (1993) A 2,500-year history of anoxia and eutrophication in Chesapeake Bay. Estuaries 16:617-626

Cooper SR, McGlothlin S, Madritch M, Jones D (2004) Paleoecological evidence of human impacts on the Neuse and Pamlico Estuaries of North Carolina, USA. Estuaries 27:617-633

Crusius J, Bothner MH, Sommerfield CK (2004) Bioturbation depths, rates and processes in Massachusetts Bay sediments inferred from modeling of ${ }^{210} \mathrm{~Pb}$ and ${ }^{239+240} \mathrm{Pu}$ profiles. Estuar Coast Shelf Sci 61:643-655

Davis JR, Koop K (2006) Eutrophication in Australian rivers, reservoirs and estuaries-a Southern Hemisphere perspective on the science and its implications. Hydrobiologia 559:23-76

Department of Environment, Heritage (DEH) (2010) Securing the future, long-term plan for the Coorong, Lower Lakes and Murray Mouth. Department of Environment and Heritage, Adelaide

Dick J, Haynes D, Tibby J, Garcia A, Gell P (2011) A history of aquatic plants in the Coorong, a Ramsar-listed coastal wetland, South Australia. J Paleolimnol. doi:10.1007/ s10933-011-9510-4
Drew S, Flett I, Wilson J, Heijins H, Skillbeck CG (2008) The trophic history of Myall Lakes New South Wales, Australia: interpretations using ${ }^{13} \mathrm{C}$ and ${ }^{15} \mathrm{~N}$ of the sedimentary record. Hydrobiologia 608:35-47

Eyre BD (2000) Regional evaluation of nutrient transformation and phytoplankton growth in nine river-dominated subtropical east Australian estuaries. Mar Ecol Prog Ser 205:61-83

Eyre B, Balls P (1999) A comparative study of nutrient behavior along the salinity gradient of tropical and temperate estuaries. Estuaries 22:313-326

Fluin J, Gell P, Haynes D, Tibby J, Hancock G (2007) Palaeolimnological evidence for the independent evolution of neighbouring terminal lakes, the Murray Darling Basin, Australia. Hydrobiologia 591:117-134

Gell P, Tibby J, Fluin J, Leahy P, Reid M, Adamson K, Bulpin S, MacGregor A, Wallbrink P, Hancock G, Walsh B (2005) Accessing limnological change and variability using fossil diatom assemblages, south-east Australia. River Res Appl 21:257-269

Geoscience Australia (2011) OzCoasts. Australian online coastal information. www.ozcoasts.gov.au. Accessed 11 Oct 2011

Grinham A, Gale D, Udy J (2011) Impact of sediment type, light and nutrient availability on benthic diatom communities of a large estuarine bay: Moreton Bay, Australia. J Paleolimnol. doi:10.1007/s10933-010-9407-7

Haese RR, Murray EJ, Smith CS, Smith J, Clementson L, Heggie D (2007) Diatoms control nutrient cycles in a temperate, wave-dominated estuary (southeast Australia). Limnol Oceanogr 52:2686-2700

Hancock GJ, Hunter JR (1999) Use of excess ${ }^{210} \mathrm{~Pb}$ and ${ }^{228} \mathrm{Th}$ to estimate rates of sediment accumulation and bioturbation in Port Phillip Bay, Australia. Mar Freshw Res 50:533-545

Hancock G, Leslie C, Everett SE, Tims SG, Brunskill GJ, Haese R (2011) Plutonium as a chronomarker in Australian and New Zealand sediments: a comparison with ${ }^{137}$ Cs. J Environ Radioact 102:919-929

Harris GP (1999) Comparison of the biogeochemistry of lakes and estuaries: ecosystem processes, functional groups, hysteresis effects and interactions between macro- and microbiology. Mar Freshw Res 50:791-811

Haynes D, Gell P, Tibby J, Hancock G, Goonan P (2007) Against the tide: the freshening of naturally saline coastal lakes, southeastern South Australia. Hydrobiologia 591: $165-183$

Haynes D, Skinner R, Tibby J, Cann J, Fluin J (2011) Diatom and foraminifera relationships to water quality in The Coorong, South Australia, and the development of a diatom-based salinity transfer function. J Paleolimnol. doi: 10.1007/s10933-011-9508-y

Hodgson DA, Tyler PA (1996) The impact of a hydro-electric dam on the stability of meromictic lakes in south west Tasmania, Australia. Arch Hydrobiol 137:301-323

Hollins E, Harrison JJ, Jones BG, Zawadzki A, Heijnis H, Hankin S (2011) Reconstructing recent sedimentation in two urbanised coastal lagoons (NSW, Australia) using radioisotopes and geochemistry. J Palaeolimnol. doi: 10.1007/s10933-011-9555-4

Hua Q (2009) Radiocarbon: a chronological tool for the recent past. Quat Geochronol 4:378-390 
Juggins S (1992) Diatoms in the Thames Estuary, England: ecology, palaeoecology and salinity tranfer function. Bibliotheca Phycologica Band 25. Cramer, Stuttgart

Kauppila P, Pitkanen H, Korhola A, Pellikka K, Vaalgamaa S, Weckstrom K (2005) Assessing ecological status of an urban estuary in the northern Baltic Sea and its recovery from pollution. Verhandlungen des Internationalen Vereins für Limnologie 29:221-225

Kerfoot WC, Robbins JA, Weider LJ (1999) A new approach to historical reconstruction: combining descriptive and experimental paleolimnology. Limnol Oceanogr 44:12321247

Lamb AL, Wilson GP, Leng MJ (2006) A review of coastal palaeoclimate and relative sea-level reconstructions using $\delta 13 \mathrm{C}$ and $\mathrm{C} / \mathrm{N}$ ratios in organic material. Earth Sci Rev 75:29-57

Leslie C, Hancock GJ (2008) Estimating the date corresponding to the horizon of the first detection of ${ }^{137} \mathrm{Cs}$ and ${ }^{239+240} \mathrm{Pu}$ in sediment cores. J Environ Radioact 99:483-490

Leyden E, Tibby J, Garcia A, Zawadzki A (2011) Unexpected post settlement freshening and increase in charophytes in Bombah Broadwater (Myall Lakes, New South Wales, Australia). J Paleolimnol. doi:10.1007/s10933-011-9566-1

Logan B, Taffs KH (2011) The Burrum River estuary: identifying reference sites for Australian sub-tropical estuarine systems using paleolimnological methods. J Paleolimnol. doi:10.1007/s10933-010-9480-y

Logan B, Taffs KH, Cunningham L (2010) Applying paleolimnological techniques in estuaries: a cautionary case study from Moreton Bay, Australia. Mar Freshw Res 61:1039-1047

Logan B, Taffs KH, Eyre BD, Zawadski A (2011) Assessing changes in nutrient status in the Richmond River estuary, Australia, using paleolimnological methods. J Paleolimnol. doi:10.1007/s10933-010-9457-x

MacGregor AJ, Gell PA, Wallbrink PJ, Hancock G (2005) Natural and post-European settlement variability in water quality of the lower Snowy River floodplain, eastern Victoria, Australia. River Res Appl 21:201-213

Mackay AW, Battarbee RW, Flower RJ, Granin NG, Jewson DH, Ryves DB, Sturm M (2003) Assessing the potential for developing internal diatom-based transfer functions for Lake Baikal. Limnol Oceanogr 48:1183-1192

Ryves DB, Juggins S, Fritz SC, Battarbee RW (2001) Experimental diatom dissolution and the quantification of microfossil preservation in sediments. Palaeogeogr Palaeoclimatol Palaeoecol 172:99-113

Saunders KM (2011) A diatom dataset and diatom-salinity inference model for southeast Australian estuaries and coastal lakes. J Paleolimnol. doi:10.1007/s10933-0109456-y

Saunders KM, Taffs KH (2009) Palaeoecology: a tool to improve the management of Australian estuaries. J Environ Manag 90:2730-2736

Saunders KM, McMinn A, Roberts D, Hodgson DA, Heijnis H (2007) Recent human-induced salinity changes in Ramsarlisted Orielton Lagoon, south-east Tasmania, Australia: a new approach for coastal lagoon conservation and management. Aquat Conserv 17:51-70

Saunders KM, Hodgson DA, Harrison J, McMinn A (2008) Palaeoecological tools for improving the management of coastal ecosystems: a case study from Lake King (Gippsland Lakes) Australia. J Paleolimnol 40:33-47

Sayer CD, Davidson TA, Jones IJ, Langdon PG (2010) Combining contemporary ecology and palaeolimnology to understand shallow lake ecosystem change. Freshw Biol 55:487-499

Sloss CR, Murray-Wallace CV, Jones BG (2007) Holocene sealevel change on the southeast coast of Australia: a review. Holocene 17:999-1014

Sloss CR, Jones BG, Brooke BP, Heijnis H, Murray-Wallace CV (2011) Contrasting sedimentation rates in Lake Illawarra and St Georges Basin, two large barrier estuaries on the southeast coast of Australia. J Paleolimnol. doi: 10.1007/s10933-011-9507-z

Spaulding SA, Lubinski DJ, Potapova M (2010) Diatoms of the United States. http://westerndiatoms.colorado.edu. Accessed 14 Sept 2011

Swetnam TW, Allen CD, Betancourt JL (1999) Applied historical ecology: using the past to manage for the future. Ecol Appl 9:1189-1206

Taffs KH, Farago LJ, Heijnis H, Jacobsen G (2008) A diatombased Holocene record of human impact from a coastal environment: Tuckean Swamp, eastern Australia. J Paleolimnol 39:71-82

Telford RJ, Vandvik V, Birks HJB (2006) Dispersal limitations matter for microbial morphospecies. Science 312:1015

Tibby J, Lane MB, Gell PA (2007) Local knowledge and environmental management: a cautionary tale from Lake Ainsworth, New South Wales, Australia. Environ Conserv 34:334-341

Tuovinen N, Weckstrom K, Virtasalo JJ (2010) Assessment of recent eutrophication and climate influence in the Archipelago Sea based on the subfossil diatom record. J Paleolimnol 44:95-108

Vaalgamaa S, Korhola A (2007) Geochemical signatures of two different coastal depositional environments within the same catchment. J Paleolimnol 38:241-260

Vos PC, de Wolf H (1993) Diatoms as a tool for reconstructing sedimentary environments in coastal wetlands-methodological aspects. Hydrobiologia 269:285-296

Wachnicka A, Gaiser E, Collins L, Frankovich T, Boyer J (2010) Distribution of diatoms and development of diatombased models for inferring salinity and nutrient concentrations in Florida Bay and Adjacent Coastal Wetlands of South Florida (USA). Estuar Coasts 33:1080-1098

Wachnicka A, Gaiser E, Boyer J (2011) Ecology and distribution of diatoms in Biscayne Bay, Florida (USA): implications for bioassessment and paleoenvironmental studies. Ecol Ind 11:622-632

Weckstrom K (2006) Assessing recent eutrophication in coastal waters of the Gulf of Finland (Baltic Sea) using subfossil diatoms. J Paleolimnol 35:571-592

Wilkinson S, Henderson A, Chen Y, Sherman B (2004) SedNet User Guide. Client Report, CSIRO Land and Water, Canberra

Zong Y, Yu F, Huang G, Lloyd JM, Yim WWS (2010) Sedimentary evidence of Late Holocene human activity in the Pearl River delta, China. Earth Surf Proc Land 35:10951102 